\title{
AISLAMIENTO DE MICROORGANISMOS CELULOLÍTICOS DEL INTESTINO DE KALOTERMES SP "TERMITA" DEGRADADORES DE EXTRACTO DE CHALA Y ALFALFA
}

\author{
ISOLATION OF CELLULOLYTIC MICROORGANISMS FROM THE INTESTINE OF \\ KALOTERMES SP TERMITE"DEGRADERS OF CHALA AND ALFALFA EXTRACT \\ José Luis, Romero Bozzetta', Julio Yerson, Quiroz Sotelo², \\ Yulexis Mayra del Carmen, Romero Canales ${ }^{2}$, Moraima Yanire, Romero Canales ${ }^{3}$
}

\section{RESUMEN}

Objetivo: Aislar microorganismos celulolíticos del intestino de las termitas para aprovechar su capacidad degradadora de chala y alfalfa, como herramienta aplicable en el proceso de degradación de forrajes. Material y Métodos: Se utilizó medio de cultivo modificado por los autores, se aisló los microorganismos celulolíticos del intestino de termitas, se sembró los microorganismos, obtenidos de los intestinos de las termitas, en dos baterías (grupos) de placas Petri: una primera batería que contenían agar peptona con extracto de chala y la otra batería con agar peptona más extracto de alfalfa. Se sembró por estrías incubándolas a $37^{\circ}$, durante 24 horas en condiciones de laboratorio. Para identificar las bacterias celulolíticas realizamos la tinción de Gram, también pruebas bioquímicas, como la catalasa, TSI, citrato de Simmons. Resultado: Los microorganismos celulolíticos obtenidos, fueron sometidos a tinción Gram que permitió identificar bacterias celulolíticas Gram (-). Se logró obtener crecimiento de bacterias celulolíticas hasta diluciones de 10-4. En las placas Petri, con medios de cultivos modificados por los autores, también se observó crecimiento de bacterias celulolíticas. Conclusión: Mediante el uso de medios de cultivos alternos, como el que se utilizó para el presente trabajo (modificado por los autores) es posible aislar enterobacterias degradadoras de celulosa. El medio de cultivo modificado a partir de agar peptona con extracto de alfalfa y chala representan una alternativa a muy bajo costo con muy buenos resultados, el cual es apropiado para el aislamiento y buen crecimiento de diferentes clases de microorganismos celulolíticos.

Palabras clave: Microorganismos Celulolíticos, Cultivo Modificado, Extracto.

\begin{abstract}
Objective: To isolate cellulolytic microorganisms from the intestines of termites to take advantage of their degradation capacity of chala and alfalfa, as an applicable tool in the process of forage degradation. Materials and methods: The authors used culture media, isolated cellulolytic microorganisms from the termite gut, and microorganisms were collected from the intestines of the termites in two batteries (groups) of Petri dishes: a first battery which contained peptone agar with chala extract and the other battery with peptone agar plus alfalfa extract. Streaks were incubated at $37^{\circ}$ for 24 hours under laboratory conditions. To identify cellulolytic bacteria we performed Gram staining, also biochemical tests, such as catalase, TSI, Simmons citrate. Result: The cellulolytic microorganisms obtained were subjected to Gram staining to identify Gram (-) cellulolytic bacteria. Growth of cellulolytic bacteria was achieved until dilutions of 10-4. In the Petri dishes, with culture media modified by the authors, growth of cellulolytic bacteria was also observed. Conclusion: It is possible to isolate cellulose degrading enterobacteriaceae through the use of alternative culture media, such as the one used for the present study (modified by the authors). The culture medium modified from peptone agar with alfalfa extract and chala represents an alternative to very low cost with very good results, which is appropriate for the isolation and good growth of different classes of cellulolíticos microorganisms.
\end{abstract}

Key word: Cellulolytic Microorganisms, Modified Culture, Extract.

\footnotetext{
$\overline{1}$ Docente. Facultad de Ciencias. Universidad Nacional José Faustino Sánchez Carrión. Lima - Perú. Email: jrbozzetta@hotmail.com

${ }^{2}$ Docente. Facultad de Ingeniería Agraria, Industrias Alimentarias y Ambiental. Universidad Nacional José Faustino Sánchez Carrión

${ }^{3}$ Lic. en Educación, especialidad Biología, Química y Tecnología de los alimentos
}

Recibido:17/03/17 Aprobado:29/03/17 


\section{INTRODUCCIÓN}

Actualmente en el mundo se procesa una gran cantidad y diversidad de residuos de celulosa, como resultado de actividades en la agricultura y la industria. Entre los residuos con alto contenido de celulosa encontramos los generados por la explotación forestal, como el aserrín, la corteza y la viruta, que usualmente son vendidos a precios mínimos o más comúnmente dispuestos de forma clandestina . Estos residuos a pesar de ser altamente estables y poseer un gran potencial energético, no tienen un uso alternativo a gran escala. Guerrero (2011).

Mateo, et al. (2002) escribe en su investigación, que como una medida de control para la calidad del ambiente, existe una regulación federal que prohíbe la quema del aserrín, por lo que en los aserraderos se regala o vende a precios mínimos, o se tira en forma clandestina para evitar su acumulación en los aserraderos. El uso del aserrín como alimento para rumiantes representa una alternativa para utilizar cantidades masivas del subproducto.

Lanfranco (2001),quien resalta citando a Cabrera y Parra(1998) que si bien las termitas son consideradas por el hombre como insectos muy dañinos, ellos poseen una importante función en la naturaleza, principalmente como descomponedoras, debido a su actividad detritívora(consumidoras de tejido muerto).Otros autores como Myles (2000) citado por Lanfranco (2001), comentan la orientación que se le puede dar en forma comercial a la función descomponedoras de desechos orgánicos, porque pueden ser útiles en lugares tales como aserraderos o basureros. El mismo autor da sentido a la termicultura como la forma de utilizar la gran biomasa de termitas, especialmente importantes en los trópicos, para actividades tales como acuicultura y avicultura, como una fuente alternativa de alimento.

Globalmente, las termitas son un grupo extremadamente exitoso de organismos que degradan la madera y, por lo tanto, son importantes tanto por su papel en la rotación de carbono en el medio ambiente como como fuentes potenciales de catalizadores bioquímicos para los esfuerzos encaminados a convertir la madera en biocombustibles. Recientemente, los datos han apoyado cualquier papel directo de las bacterias simbióticas en el intestino de las termitas en celulosa y la hidrólisis de xilano. Warnecke, et al (2007).

El estudio de las termitas ha estado vinculado a su poder destructivo y apetito insaciable, y no es novedad que en muchos países causa pérdidas de millones de dólares anuales. Se han escrito tomos completos sobre ellas, así tenemos los de Grassé (1982), donde abarca la anatomía, la fisiología y la reproducción de las termitas a profundidad y otras muchas investigaciones. También hay quienes las estudian para encontrar una alternativa para controlarlas cuando se convierten en plagas. $Y$ hay investigadores que buscan alternativas productivas aprovechando el regalo de la naturaleza, como
Canessa y Berrocal (2006) quienes mencionan que no hay madera que sea inmune al ataque de estos insectos, pues colonizan cualquier tipo de madera.

Dentro del trabajo realizado por Acosta \& Lara (2013) dice que las termitas halladas y recolectadas en los árboles de mangle del estuario de la Ciénaga de la Caimanera en el municipio de Coveñas, departamento de Sucre pertenecen al género Nasutitermes especie nigriceps (Haldeman, 1853; Abadía y Arcila, 2009), el cual se agrupa dentro de la familia Termitidae (Matsui, et al., 2009). Esta familia de termitas tiene una dieta basada principalmente en hojarasca, madera y pastos (Fernández, et al., 2008), para lo cual, poseen bacterias intestinales con actividad celulolítica que facilitan la digestión de estos materiales. En este sentido, para el caso de las termitas Nasutitermes, según Wenzel, et al., (2002), se ha demostrado que las bacterias que habitan en sus intestinos contribuyen con la digestión de la celulosa.

Poco a poco el enfoque se va profundizando y llegamos a encontrar múltiples investigaciones respecto al mecanismo que utilizan las termitas para degradar la madera. Así Grassé (1982) menciona que la madera, por su alto contenido de celulosa, es el alimento predilecto de un gran número de termitas, pero su proceso constituye una digestión difícil porque la degradación de la celulosa exige un arsenal poderosísimo de enzimas y porque una fracción importante de la celulosa de la madera está ligada auna sustancia muy resistente a las enzimas, la lignina. Más adelante menciona que muchos animales procesan la celulosa con la ayuda de organismos microscópicos que la degradan. A esta asociación con beneficiosrecíprocos se le conoce como simbiosis, que se da entre el animal superior y la bacteria u hongo. Canessa y Berrocal (2006) resaltan que el éxito de las termitas, consiste en que poseen un grupo de microorganismos en su tracto digestivo, que le ayudan a la degradación del material lignocelulósico. Grassé (1982) dice que muchos mamíferos herbívoros, como los rumiantes, perisodáctilos, lagomorfos y hiracoides, poseen una cámara de fermentación en su tubo digestivo donde las bacterias anaeróbicas someten a la celulosa a su acción fermentativa. $Y$ en las termitas, las bolsas de fermentación están situadas en el trayecto del intestino posterior y la degradación de la celulosa se lleva a cabo aquí ya sea por parte de bacterias o zooflagelados. Hoy en día se reconoce que la capacidad de las termitas para degradar la celulosa por ellas mismas es más grande de lo que suponíamos.

Para la identificación de las bacterias celulolíticas se usaron técnica de coloración y técnicas bioquímicas según Aquiahuatl, et al. (2012). Ya que se conoce que, para el proceso de identificación bacteriana tradicional, la experiencia del microbiólogo es fundamental para la elección de una prueba o una batería de pruebas de forma secuencial, en función de la fiabilidad de las mismas, del género o de la especie bacteriana que se pretende identificar, del origen del aislado 
bacteriano, asl como del coste de las mismas. Los laboratorios deben elaborar y realizar un proceso de identificación normalizado en su actividad diaria, que utilice de forma secuencial o simultánea un conjunto de pruebas cuyo propósito final sea la identificación del microorganismo a nivel de género y especie y que incluya la mayoría de las bacterias desde el punto de vista infeccioso. Fernández, et al (2010)

\section{MATERIAL Y METODOS}

El trabajo experimental se realizó en el laboratorio multifuncional de Biología de la Facultad de Ciencias.

- Materia Prima: Se recolectaron Kalotermes sp "termitas" de troncos de eucalipto seco del Centro Poblado de Medio Mundo, distrito Végueta, provincia Huaura, departamento de Lima.

- Se obtuvo extracto de las hojas de chala y alfalfa.

- Pre tratamiento de las "termitas": Las termitas fueron lavadas con jabón antibacterial y posteriormente, se procedió a diseccionarlas en Solución Salina Fisiológica (SSF) al 0,9\%, con un bisturí; para dejar al descubierto sus intestinos. Luego se tomó una muestra (asada) de contenido intestinal que fue introducida en dos tubos de ensayo que contenían $10 \mathrm{ml}$ de agua peptonada cada uno, agitándolos suavemente hasta obtener una muestra homogénea.

- Se procedió a preparar la solución madre donde se agregó a un matraz $90 \mathrm{ml}$ de agua peptonada y $10 \mathrm{ml}$ de muestra.

- Se inocularon $1 \mathrm{ml}$ de solución madre en tubos con 9 $\mathrm{ml}$ agua peptonada. Hasta completar las diluciones de 10-6.

- Preparación de Medios de Cultivo: En cuanto a la elaboración del medio de cultivo modificado que utilizamos, está compuesto por agar peptona con extracto de alfalfa o chala en cantidades establecidas por los autores, que constituye una alternativa para el aislamiento de microorganismo ya que minimizan los costos y la utilización de sustancias químicas adicionales como los que cita Acosta et al (2013), que utilizan como medio de cultivo Luria Bertani (LM) suplementado con Carboximetil celulosa (CMC) $2 \%$ $\mathrm{p} / \mathrm{v}$.

- Siembras en placas Petri: De los tubos con crecimiento positivo, se cogió una alícuota y se sembró en dos baterías (grupos) de placas Petri: una primera batería de placas Petri que contenían agar peptona con extracto de chala y la otra batería de placas Petri con agar peptona más extracto de alfalfa.

- Para la siembra se empleó el método de estrías y fueron incubados a $37^{\circ}$, durante 24 horas en condiciones de laboratorio.

- Para la identificación de las bacterias celulolíticas se realizó la tinción de Gram, así como también pruebas bioquímicas, como la catalasa, TSI, citrato de Simmons.
Flujograma para el Aislamiento de Microorganismos Celuloliticos del intestino de Kalotermes sp "Termita" degradadores de extracto de Chala y Alfalfa.

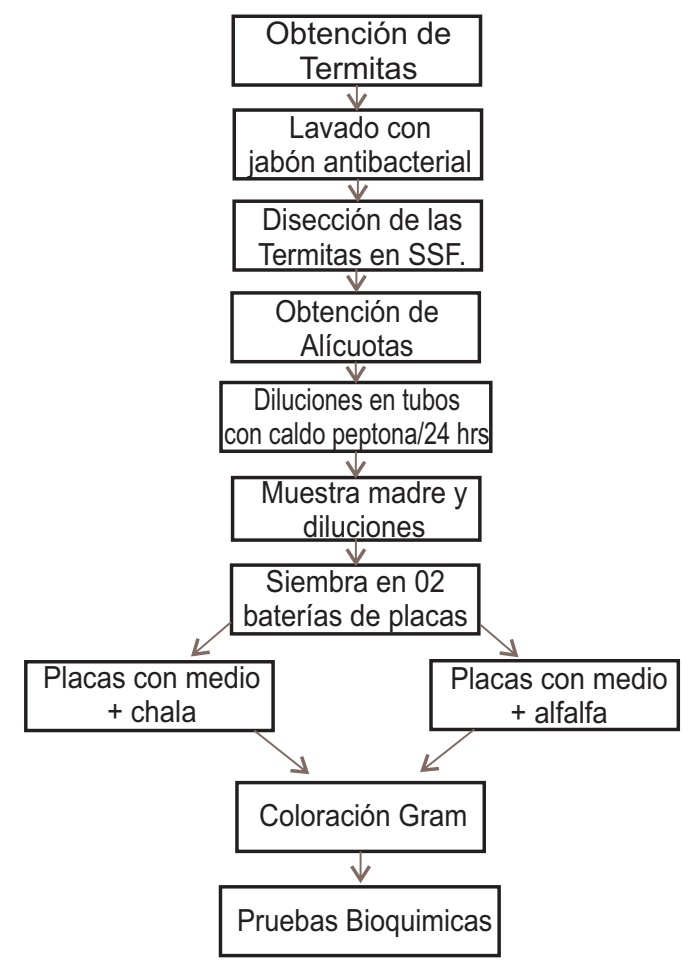

\section{RESULTADOS Y DISCUSIÓN}

- Las termitas recolectadas de madera seca de eucalipto del Centro Poblado de Medio Mundo, distrito Végueta, provincia Huaura, del departamento de Lima, pertenecen a la especie Kalotermes sp, el cual se agrupa dentro de la familia Kalotermitidae.

- La tinción de Gram permitió observar bacterias celulolíticas Gram (-).

- Se observó crecimiento de bacterias celulolíticas hasta diluciones de 10-4.

- En las siembras de placas Petri con medios de cultivos modificados por los autores, también se observó crecimiento de bacterias celulolíticas.

\section{CONCLUSIONES}

- Los inóculos utilizados para el aislamiento de las bacterias, se obtuvieron de las termitas colectadas de troncos secos de Eucalipto sp,

- Mediante el uso de medios de cultivos alternos, como el que se utilizó para el presente trabajo (modificado por los autores) es posible aislar enterobacterias degradadoras de celulosa.

- El medio de cultivo modificado por los autores, a partir de agar peptona con extracto de celulosa de alfalfa y chala; representan una alternativa a muy bajo costo con muy buenos resultados, el cual es apropiado para el aislamiento y buen crecimiento de diferentes clases de microorganismos celulolíticos.

- El estudio es parte inicial de un proyecto; que tiene como meta producir un inóculo de bacterias celulolíticas que permitan la incorporación de las 
mismas en la alimentación de animales menores.

-Es importante continuar con los procesos de investigación con bacterias celulolíticas, que permitan conocer las condiciones necesarias para su óptimo desarrollo e identificar los productos que se generan.

\section{AGRADECIMIENTO}

Se agradece a los alumnos de la E.P. de Ingeniería Zootécnica, por la ayuda prestada durante las pruebas microbiológicas. Al Sr. Laguna Cauzo, José; técnico del Laboratorio multifuncional de Biología, por su encomiable servicio.

\section{REFERENCIAS BIBLIOGRÁFICAS}

Acosta, R. \& Lara, C. (2013) Bacterias celulolíticas aisladas del intestino de termitas ( Nasutetermes nigriceps) con características probióticas y potencial en la degradación del pasto. Revista Colombiana de Biotecnología, 15, 8-16.

Aquiahuatl, M., Volke, T., Prado, L., Shirai, K., Ramírez, F. \& Salazar, M. (2012) Manual de prácticas de laboratorio de Microbiología general. Iztapalapa: CBS.

Canessa, E. \& Berrocal, A. (2006) Las termitas: un enemigo silencioso. Kurú: Revista Forestal 3

Fernández, A., García, C., Saéz, J. \&Valdezate, S. (2010) Métodos de identificación bacteriana en el laboratorio de microbiología. España: Emilia Cercenado y Rafael Cantón.

Grassé, P.P. (1982). Termitología. Tomo I: Anatomía, fisiología y reproducción de termitas. París: Masson.

Guerrero, A. (2011) Aislamiento de bacterias ruminales degradadoras de celulosa. Tesis para optar el título de Ingeniera Ambiental, Universidad Politécnica Salesiana, Cuenca, Ecuador.

Lanfranco, D.(2001)Descripción de la biología, daño y control de las termitas: especies existentes en Chile. Bosque 22, 77-84.

Mateo, J., Cobos, M., Trinidad, A., Cetina, V. \& Vargas, J. (2002) Aislamiento de bacterias ruminales degradadoras del aserrín. Agrociencia 36, 523-530.

Warnecke, F. et al(2007). Metagenomic and functional analysis of hindgut microbiota of a wood-feeding higher termite. Revista nature, 450 . 